\title{
Blankaartia sinnamaryi (Trombidiformes: Trombiculidae) parasitizing birds in southeastern Brazil, with notes on Rickettsia detection
}

\author{
Blankaartia sinnamaryi (Trombidiformes: Trombiculidae) parasitando aves no sudeste do Brasil, \\ e notas sobre a detecçáo de Rickettsia
}

Ricardo Bassini-Silva ${ }^{1}$; Fernando de Castro Jacinaviciuss ${ }^{1,2}$; Ralph Maturano ${ }^{3}$; Sebastián Muñoz-Leal ${ }^{1}$; Ronald Ochoa ${ }^{4}$; Gary Bauchan ${ }^{5}$; Marcelo Bahia Labruna ${ }^{1}$; Darci Moraes Barros-Battesti ${ }^{6^{*}}$

\begin{abstract}
${ }^{1}$ Departamento de Medicina Veterinária Preventiva e Saúde Animal, Faculdade de Medicina Veterinária e Zootecnia - FMVZ, Universidade de Sáo Paulo - USP, São Paulo, SP, Brasil

${ }^{2}$ Laboratório Especial de Coleçóes Zoológicas, Instituto Butantan, São Paulo, SP, Brasil

${ }^{3}$ Departamento de Zoologia, Instituto de Ciências Biológicas, Universidade Federal de Juiz de Fora, Juiz de Fora, MG, Brasil

${ }^{4}$ Systematic Entomology Laboratory, United States Department of Agriculture, Agricultural Research Service, Beltsville, MD, USA

${ }^{5}$ Electron \& Confocal Microscopy Unit, United States Department of Agriculture, Agriculture Research Service, Beltsville, MD, USA

${ }^{6}$ Departamento de Patologia Veterinária, Faculdade de Ciências Agrárias e Veterinárias - UNESP, Jaboticabal, SP, Brasil
\end{abstract}

Received May 02, 2018

Accepted July 11, 2018

\begin{abstract}
The larvae of the family Trombiculidae are ectoparasites of vertebrates, including birds. The bite of some species can cause deep lesions and severe skin reactions in the host, these can lead to dermatitis, popularly known as trombiculiasis. A morphological study of chiggers collected on birds from the state of Minas Gerais in Southeastern Brazil discovered Blankaartia sinnamaryi-infestation on Passeriformes birds. Molecular studies of the disclosed the $18 \mathrm{r}$ rDNA sequences of the mite, and the detection of a Rickettsia sp. in this chigger mite species.
\end{abstract}

Keywords: Chiggers, Rickettsia, passeriformes, dermatitis.

\section{Resumo}

As larvas da família Trombiculidae são ectoparasitas de vertebrados, incluindo aves. A picada de algumas espécies pode causam lesóes profundas e reaçôes cutâneas graves no hospedeiro, estas podem levar a dermatites, popularmente conhecidas como trombiculíases. Por meio de um estudo morfológico dos espécimes coletados parasitando aves do estado de Minas Gerais, Sudeste do Brasil relatou a infestação por Blankaartia sinnamaryi em aves Passeriformes. Além disso, nós fornecemos sequências de rDNA $18 \mathrm{~S}$ desses ácaros e a detecção de uma espécie de Rickettsia sp. nesta espécie de trombiculídeo.

Palavras-chave: Trombiculídeos, Rickettsia, passeriformes, dermatite.

\section{Introduction}

Chigger mites of Trombiculidae family Ewing, 1944 are represented by ca. 3000 species (HOFFMANN, 1990). In Brazil, eight species of this family have been documented parasitizing birds (BRENNAN \& GOFF, 1977; BASSINI-SILVA et al., 2017). Until now, Parasecia thalurania Brennan, 1969 was found parasitizing birds

*Corresponding author: Darci Moraes Barros-Battesti. Departamento de Patologia Veterinária, Faculdade de Ciências Agrárias e Veterinárias, Universidade Estadual Pualista - UNESP, Rua Castellane, s/n, Via de Acesso Professor Paulo Donato Castelane, Vila Industrial, CEP 14884-900, Jaboticabal, São Paulo, Brasil. e-mail: barros.battesti@gmail.com of the order Apodiformes (BRENNAN, 1969); Apolonia tigipioensis Torres \& Braga, 1938 and Eutrombicula batatas (Linnaeus, 1758) were associated to some representatives of the order Galliformes (TORRES \& BRAGA, 1938; EWING, 1925; CONFALONIERI \& DE CARVALHO, 1973); A. tigipioensis, Blankaartia sinnamaryi (FLOCH \& FAURAN, 1956), Parasecia fundata Brennan, 1969 and Neoschoengastia esorhina Brennan, 1971 were found parasitizing species of the order Passeriformes (ORNELAS-ALMEIDA et al., 2007; FLOCH \& FAURAN, 1956; BRENNAN, 1969, 1971); $B$ sinnamaryi was found parasitizing species of the order Piciformes (FLOCH \& FAURAN, 1956); A. tigipioensis was found parasitizing 
species of the order Struthioniformes (ORNELAS-ALMEIDA et al., 2007); A. tigipioensis and Eutrombicula tinami Oudemans, 1910 were found parasitizing species of the order Tinamiformes (ORNELAS-ALMEIDA et al., 2007; OUDEMANS, 1910); and only one species, Blankaartia shatrovi Bassini-Silva \& Barros-Battesti, 2017, was collected on an unidentified bird (BASSINI-SILVA et al., 2017).

Some larvae species of the family Trombiculidae can cause deep lesions and severe skin reactions in the host because of bites (HASE et al., 1978), which can lead to dermatitis, popularly known as trombiculiasis (STEKOLNIKOV et al., 2014). One of the first cases of trombiculiasis documented on birds was reported by TORRES \& BRAGA (1938) in Pernambuco, Brazil, who described chiggers of $A$. tigipioensis causing nodular lesions on the quill of domestic chickens. SPALDING et al. (1997), reported the species $B$. sinnamaryi caused dermatitis similar to $A$. tigipioensis in domestic chickens from the state of Florida, USA. Recently, MAKOL \& KORNILUK (2017), reported the species Blankaartia acuscutellaris (Walch, 1923) causing lesions, when in large quantity, in the species Gallinago media (Charadriiformes: Scolopacidae), in Poland. They even noticed that the parasitized regions had a thick epidermis and no plumage. As is well known, chiggers are not host-specific, and several cases of human bites have also been reported (HEYNE et al., 2001; TAKAHASHI et al., 2004; RIPKA \& STEKOLNIKOV, 2006; BURNS, 2010; SHATROV \& STEKOLNIKOV, 2011).

Birds are known spreaders of ectoparasites including ornithophylic chigger mites. When mites are attached, their hosts can transport them remarkable distances, and eventually move infected chiggers from one place to another, which directly contributes to the dissemination of associated bacteria (VARMA, 1964). In the past, public health departments were faced with the need for cataloging and understanding the biology of these mites due to their potential role as Rickettsia vectors (WHARTON \& FULLER, 1952). Recently in Slovakia, Rickettsia monacensis and Rickettsia helvetica were molecularly detected in Hirsutiella zachvatkini (Schluger, 1948), and in addition, $R$. monacensis was found associated with Kepkatrombicula storkani (Daniel) (MIŤKOVÁ et al., 2015). In particular, the current role of chigger mites in the epidemiology of rickettsiosis is still unknown in the Neotropics (AZAD \& BEARD, 1998; POINAR \& POINAR, 1998). Recently WEITZEL et al. (2016) found the presence of the bacterium, Orientia tsutsugamushi, in humans, suggesting the possible transfer by a bite from chiggers in these patients. In Brazil, FONSECA (1932) emphasized the importance of bloodsucking mites as potential vectors in the epidemiological cycle of rickettsial diseases. Nevertheless, the role of trombiculid mites as vectors has never been confirmed.

The purpose of this study is to conduct morphological and molecular studies of chiggers collected on birds from the state of Minas Gerais in Southeastern Brazil and determine if Rickettsia could be present in these chiggers.

\section{Material and Methods}

\section{Collection of mites}

Thirty-four field trips, each lasting five days, were made during March 2013 and December 2015 at the Botanical Garden of the Universidade Federal de Juiz de Fora, Juiz de Fora, Minas Gerais
( $21^{\circ} 43^{\prime} \mathrm{S}, 43^{\circ} 22^{\prime} \mathrm{W}$, elevation $852 \mathrm{~m}$ ), with the authorization of the System of Authorization and Information on Biodiversity (SISBIO, protocol number 29268) and The National Center for Bird Conservation (CEMAVE, protocol number 3954). Birds were captured using 10 ornithological mist nets $(12 \mathrm{~m}$ long $\times 3 \mathrm{~m}$ wide, $16 \mathrm{~mm}$ mesh) between $06.00 \mathrm{~h}$ and $16.00 \mathrm{~h}$ each day. Trapped birds were weighed, measured and photographed, with identifications established following (RIDGELY \& TUDOR, 2009). Birds were examined for the presence of mites by checking their entire body. In the laboratory, the specimens were counted and separated for slide-mounting for morphological studies using a microscope, scanning electron microscopy studies, and DNA extraction with the help of a stereomicroscope Nikon SMZ745T (Sao Paulo, Brazil).

\section{Morphological identification of mites}

The material was slide-mounted and deposited into the Acari Collection of the Instituto Butantan, São Paulo, Brazil (IBSP). Chiggers were identified based on the original descriptions of all species of the genus Blankaartia (EWING, 1926; FLOCH \& ABONNENC, 1941; BOSHELL \& KERR, 1942; MICHENER, 1946; FLOCH \& FAURAN, 1956; RADFORD, 1957; VERCAMMEN-GRANDJEAN, 1960; TAUFFLIEB \& MOUCHET, 1959; BRENNAN \& JONES, 1961; BRENNAN, 1965; BRENNAN \& YUNKER, 1966; CROSSLEY \& ATYEO, 1972; TAUFFLIEB, 1972; NADCHATRAM \& GOFF, 1980; BASSINI-SILVA et al., 2017) and by comparison with type and material slides that were deposited at the USNM (Appendix 1), which are housed at the Systematic Entomology Laboratory (USDA-ARS, BARC). Some specimens were also prepared for Scanning Electron Microscopy (SEM) according to WALTER \& KRANTZ (2009) with a Digital Scanning Electron Microscope FEI (Hillsboro, Oregon USA), Quanta 250, at the Laboratory of Cell Biology, Instituto Butantan. The terminology of GOFF et al. (1982), with adaptations proposed by STEKOLNIKOV (2008) and STEKOLNIKOV \& DANIEL (2012) concerning general nomenclature of larval stages was followed with the terminology for specialized setae using KETHLEY (1990), WOHLTMANN et al. (2006, 2007) and BASSINI-SILVA et al. (2017). Voucher specimens have been deposited at the IBSP collection, under the accession numbers found on table 1 .

\section{Molecular tools}

\section{DNA extraction}

Forty field-collected larvae (Table 1) were individually subjected to DNA extraction using the Guanidine Isothocianate (GT) lysis protocol following CHOMCZYNSKI (1993). Each mite was placed in an Eppendorf microtube, and punctured in the idiosomal region with a sterile needle (1.20*40-18G). After DNA extraction, exoskeletons of the specimens were recovered and slide-mounted for observations in a microscope in order to perform morphological identifications. 
PCR

PCR technology was used initially performed following OTTO \& WILSON (2001), SIMON et al. (1994) and NAVAJAS et al. (1994) to target a partial fragment of the mite $18 \mathrm{~S}$ ribosomal gene and two PCR protocols were used to amplify a section of the mite mitochondrial cytochrome oxidase I (COI) gene. All the reactions were performed using DNA extracted from the trombiculid Quadraseta brasiliensis Goff \& Gettinger (1989) as positive and DNA-free Milli-Q water as negative controls. $18 \mathrm{~S}$ gene PCR was used as endogenous control, and negative samples were excluded from further analyses. The presence of Rickettsia DNA was detected by, through the use of PCR, targeting partial fragments of the rickettsial genes gltA (LABRUNA et al., 2004), ompA (REGNERY et al., 1991), and ompB (ROUX \& RAOULT, 2000) genes. Primers used in the reactions are listed in Table 2. Reactions yielding amplicons of expected size were purified using the Qiagen (Sao Paulo, Brazil) MinElute kit following the manufacturer instructions. Sanger sequencing of the samples was performed at the "Centro de pesquisa sobre Genoma Humano e Células Tronco do Instituto de Biociências da USP”. Sequences that were obtained were assembled and the primer trimmed with Geneious R9 (KEARSE et al., 2012), and then submitted to a BLAST analysis (www.ncbi.nlm.nih.gov/blast) in order to infer closest similarities with other homologous sequences (ALTSCHUL et al., 1990).

\section{Results}

\section{Bird captures and collection of mites}

A total of 95 mites were collected on six bird species (Table 1). Two specimens of the species Chiroxiphia caudata (Passeriformes: Pipridae) were captured and four chiggers were collected in these hosts; five specimens of the species Tachyphonus coronatus (Passeriformes: Thraupidae) were captured and twenty seven chiggers were collected in these hosts; two specimens of the

Table 1. Specimens of Blankaartia sinnamaryi collected on birds from March 2013 to May 2016, in the Botanical Garden of the Universidade Federal de Juiz de Fora, Juiz de Fora, Minas Gerais, Brazil.

\begin{tabular}{|c|c|c|c|}
\hline Host Family & Host Species & IBSP accession number & $\begin{array}{l}\text { No. of B. sinnamaryi } \\
\text { specimens collected (No. specimens tested by PCR) }\end{array}$ \\
\hline \multirow[t]{3}{*}{ Pipridae } & Chiroxiphia caudata & 12331 & $2(2)$ \\
\hline & Chiroxiphia caudata & 12336 & $2(2)$ \\
\hline & Manacus manacus & 12338 & $4(2)$ \\
\hline \multirow[t]{5}{*}{ Thraupidae } & Tachyphonus coronatus & $12323 \mathrm{~A}$ & $10(4)$ \\
\hline & Tachyphonus coronatus & 12343 & $7(2)$ \\
\hline & Tachyphonus coronatus & 12340 & $4(2)$ \\
\hline & Tachyphonus coronatus & 12342 & $4(2)$ \\
\hline & Tachyphonus coronatus & 12351 & $2(2)$ \\
\hline \multirow[t]{2}{*}{ Troglodytidae } & Troglodytes musculus & $12344 \mathrm{~A}$ & $20(2)$ \\
\hline & Troglodytes musculus & $12345 \mathrm{~A}$ & $36(16)$ \\
\hline Turdidae & Turdus rufiventris & 12350 & $2(2)$ \\
\hline Tyrannidae & Lathrotriccus euleri & 12348 & $2(2)$ \\
\hline Total & & & $95(40)$ \\
\hline
\end{tabular}

Table 2. Primers for endogenous control and detection of Rickettsia spp.

\begin{tabular}{|c|c|c|c|c|}
\hline Target & Genes & Names and DNA sequences $\left(5^{\prime}-3^{\prime}\right)$ of the primers & Fragment size & Reference \\
\hline \multirow[t]{6}{*}{ Chiggers } & $18 \mathrm{~S}$ & 18S-1R: ATATTGGAGGGCAAGTCTGG & $-650-b p$ & Otto and Wilson (2001) \\
\hline & & 18S-1R: TGGCATCGTTTATGGTTAG & & \\
\hline & COI-1 & CI-J-175I: GGWGCWCCWGAYATRGCWTTYCC & 950-bp & Simon et al. (1994) \\
\hline & & CI-N-219I: GGWARAATTAAAATATAWACTTC & & \\
\hline & & 772: TGATTTTTTGGTCACCCAGAAG & 408-bp & Navajas et al. (1994) \\
\hline & & 773: TACAGCTCCTATAGATAAAAC & & \\
\hline \multirow[t]{8}{*}{ Rickettsia spp. } & glt $A$ & CS 78 F: GCAAGTATCGGTGAGGATGTAAT & 401-bp & Labruna et al. (2004) \\
\hline & & CS 323 R: GCTTCCTTAAAATTCAATAAATCAGGAT & & \\
\hline & & CS-239 F: GCTCTTCTCATCCTATGGCTATTAT & $830-\mathrm{pb}$ & Labruna et al. (2004) \\
\hline & & CS-1069 R: CAGGGTCTTCGTGCATTTCTT & & \\
\hline & $o m p A^{*}$ & Rr 190.70 F: ATGGCGAATATTTCTCCAAAA & 532-bp & Regnery et al. (1991) \\
\hline & & Rr 190.701 R: GTTCCGTTAATGGCAGCATCT & & \\
\hline & $o m p B$ & 120.M59 F: CCGCAGGGTTGGTAACTGC & 862-bp & Roux and Raoult (2000) \\
\hline & & 120-807 R: CCTTTTAGATTACCGCCTAA & & \\
\hline
\end{tabular}

\footnotetext{
${ }^{*}$ Rickettsia of the Spotted Fever Group.
} 
species Troglodytes musculus (Passeriformes: Troglodytidae) were captured and fifty six chiggers were collected in these hosts; one specimen of the species Manacus manacus (Passeriformes: Pipridae), Turdus rufiventris (Passeriformes: Turdidae), and Lathrotriccus euleri (Passeriformes: Tyrannidae) were captured and two mites were collected in each of these hosts species.

The chiggers were identified as Blankaartia sinnamaryi (FLOCH \& FAURAN, 1956) by the following combination of external characters: genu of the leg I with three sigma, tarsus of the leg III with one mastisetae, on the $\mathrm{C}$ row of dorsal idiosomal setae with eight setae, palp tarsus with seven branched setae, galealae branched, odontus trifurcated (Figure 1). These mites were collected from different regions of the birds, including the flank and upper body, which exhibited a deep skin lesion in the area where mites were attached (Figure 2).

\section{Molecular tools}

Only 29 of 40 samples were positive to the $18 \mathrm{~S}$ gene via PCR and attempts to sequencing expected size amplicons were successful only for three samples that yielded an identical haplotype of 456-bp (GenBank accession numbers: MG783391). Attempts
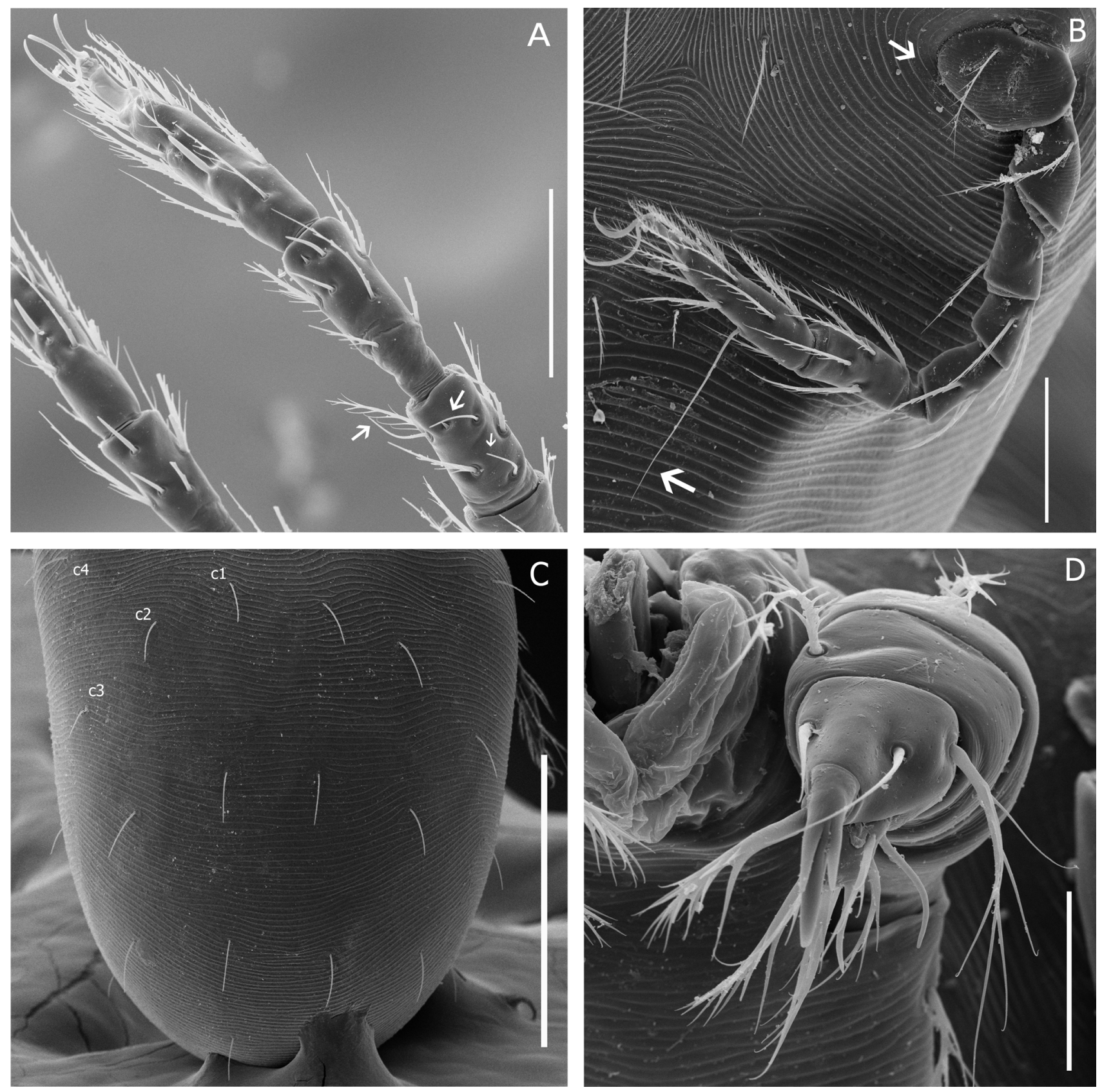

Figure 1. Morphological details of Blankaartia sinnamaryi. A - leg I; B - leg III; C - dorsal opisthosomal setae; D - palpal genu, tibia and tarsus. The white arrows highlight the specialized setae of the segments of the legs I and III and the striate coxae III; $c 1-c 4=$ setae of the C row; The Scale bars: A and B $50 \mu \mathrm{m}$, C $300 \mu \mathrm{m}, \mathrm{D} 20 \mu \mathrm{m}$. 

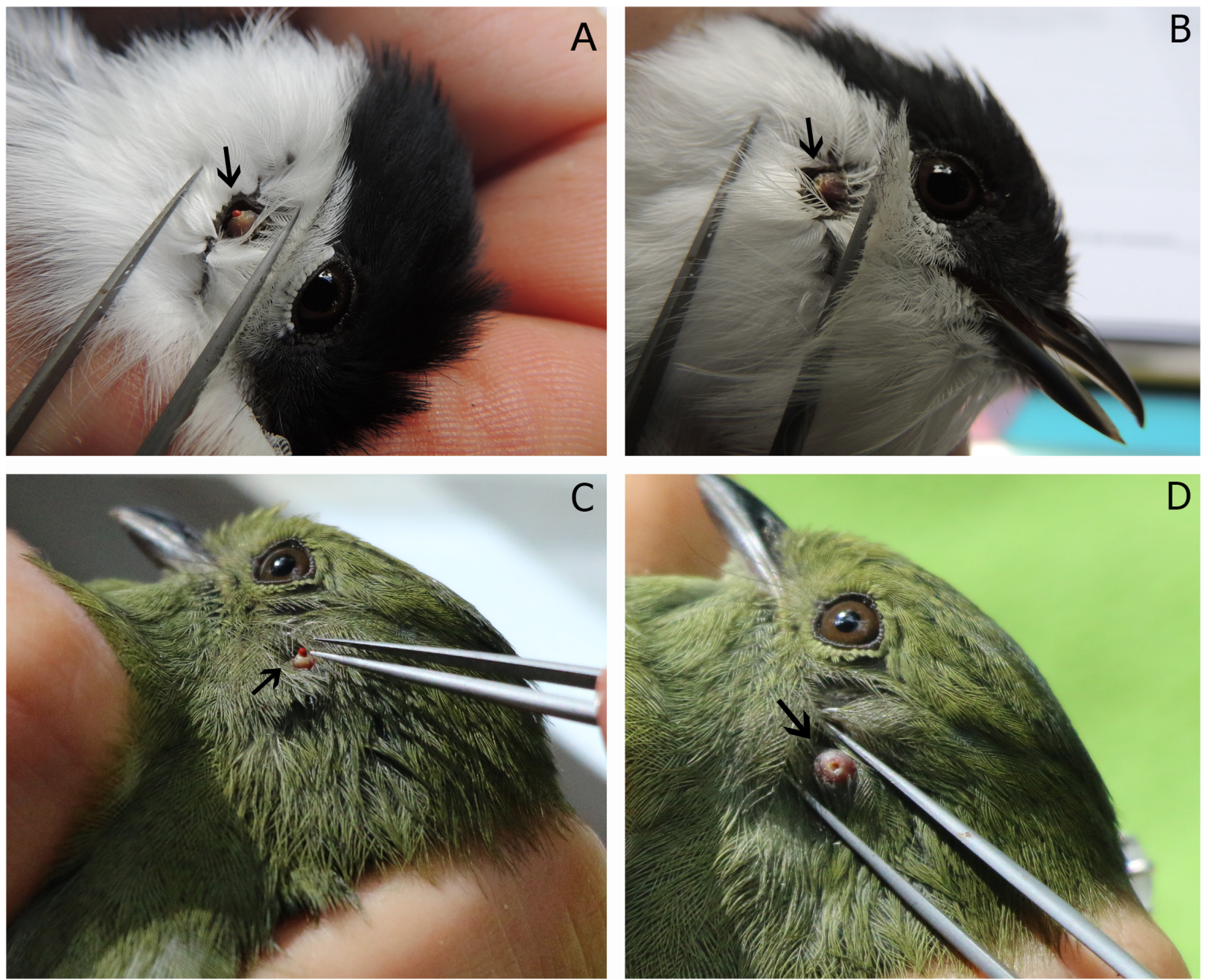

Figure 2. Blankaartia sinnamaryi parasitizing birds. A - Manacus manacus (ð̋) parasitized by one chigger; B - Injury on Manacus manacus (ð) after removal of the mite; C - Manacus manacus ( $(+)$ parasitized by one chigger; D - Injury on Manacus manacus $($ ( $)$ after removal of the mite.

to amplify fragments of the COI gene were unsuccessful. After a BLAST analysis, the consensus of these three $18 \mathrm{~S}$ sequences was 98.9\% (451/456-bp) identical to the corresponding sequence of Eutrombicula splendens (Ewing, 1913) (KP325057), and 98.7\% (450/456-bp) identical to Quadraseta brasiliensis Goff \& Gettinger, 1989 (KY934464, MF113412, and MF113413). Three out of the 29 18S-positive samples were positive for rickettsial $g l t A$ gene; however only one of them yielded a clean (but short) sequence after sequencing attempts. After a BLAST analysis, the sequence shown to be 100\% (1011/1011-bp) identical with Rickettsia felis (JQ674484, JN375498 and CP000053). Attempts to amplify fragments of the $\operatorname{omp} A$ and $\operatorname{omp} B$ genes were unsuccessful. The Rickettsia sp. sequence obtained in this study has been deposited in GenBank under accession number MG783574.

\section{Discussion}

Blankaartia sinnamaryi has already been collected on birds; however, three new host associations are added by the results of this study: Chiroxiphia caudata, Lathrotriccus euleri and
Troglodytes musculus (Table 1). Captured birds were visually examined in search for mites, Figure 2 shows a local dermal lesion by only one mite. Similar injuries caused by trombiculid mites have already been noted by TORRES \& BRAGA (1938) and SPALDING et al. (1997).

All collected mites were morphologically identified as $B$. sinnamaryi and were able to be genetically characterized using the $18 \mathrm{~S}$ rRNA gene. The nuclear small ribosomal subunit gene has been pointed to be slow evolving, which favors the use of universal primers to amplify sequences in genetically unidentified species (HILLIS \& DIXON, 1991). However, this slow rate of evolution precludes a good separation of taxa to the genera level and would be phylogenetically more informative in higher groupings among eukaryotes (HILLIS \& DIXON, 1991). Although partial fragments were compared the $18 \mathrm{~S}$ sequences from $B$. sinnamaryi are highly similar $(<99 \%)$ to other trombiculid species (i. e. E. splendens and Q. brasiliensis), which reflects that all three species belong to a same family of mites. Unfortunately, no sequences of less-conserved COI gene were obtained, which in turn would be certainly more informative in separating the morphological identity of B. sinnamaryi from a genetic point of view. 
JACINAVICIUS et al. (2018) and this study was successful in amplifying the $18 \mathrm{~S}$ gene for chiggers. The same pair of primers for the gene COI used by KAMPEN et al. (2004) was used to amplifying successfully the sequences for the species Neotrombicula autumnalis (SHAW \& NODDER, 1790). Because this was successful, it was expected that $B$. sinnamaryi samples would amplify the COI gene, however none were detected.

The detection of Rickettsia DNA in B. sinnamaryi is not surprising, since bacteria of this genus have already been found in chiggers parasitizing birds and rodents in Europe and Asia (HASE et al., 1978; TAKAHASHI et al., 2004; MIŤKOVÁ et al., 2015). Apart from early suppositions for the American Continent, chiggers infesting rodents would be harboring Rickettsia spp. (FONSECA, 1932), however, no current evidence has been published. The larvae of $B$. sinnamaryi collected on the bird Tachyphonus coronatus was found to be positive for Rickettsia gltA gene via PCR. Though a BLAST comparison it can be inferred that the obtained sequence perfectly $(100 \%)$ matched the Rickettsia felis sequence. A cautious presumption should be adopted, and consider the bacterium found in B. sinnamaryi as a $R$. felis-like agent, because further attempts to amplify omp $A$ and $\operatorname{omp} B$ genes were unsuccessful. Notwithstanding, primers used for $g l t A$ amplification are specific for the Rickettsia genus (LABRUNA et al., 2004), which confirms that $B$. sinnamaryi could be indeed carrying a rickettsial agent which would require additional molecular characterization. It is worthy to mention that chiggers were collected which appeared to be engorged, which raises the possibility that the detection of Rickettsia might be the result of a rickettsaemic bird. However, this supposition becomes hardly possible, since current evidence has demonstrated that birds are immune to Rickettsia infection, possibly due to their higher body temperature $\left(>40{ }^{\circ} \mathrm{C}\right)$, since it is practically impossible to grow Rickettsia in such temperature under in vitro conditions (OGRZEWALSKA \& PINTER, 2016).

\section{Acknowledgements}

To Gabrielle Ribeiro de Andrade and Maria Cristina Ferreira do Rosário for technical contributions (CNPq no. 377343/20153 and 377342/2015-7, respectively). To Beatriz Mauricio of the Laboratory of Cellular Biology of the Instituto Butantan for the images obtained through the Scanning Electron Microscopy. To Debra D. Creel for technical support. To Felipe da Silva Krawczak, for providing advice in molecular techniques. This work was supported by the Conselho Nacional de Desenvolvimento Científico e Tecnológico (CNPq no. 454907/2014-1 and 440639/2015-8 to DMB-B, 377976/2014-8 to FCJ), Coordenaçáo de Aperfeiçoamento de Pessoal de Nível Superior (CAPES) (No. 032/2010) to RM and Fundação de Amparo à Pesquisa do Estado de São Paulo (FAPESP no. 2010/51875-9 to DMB-B and 2017/01416-7 to RB-S). Mention of trade names or commercial products in this publication is solely for the purpose of providing specific information and does not imply recommendation or endorsement by the USDA; USDA is an equal opportunity provider and employer.

\section{References}

Altschul SF, Gish W, Miller W, Myers EW, Lipman DJ. Basic local alignment search tool. J Mol Biol 1990; 215(3): 403-410. http://dx.doi. org/10.1016/S0022-2836(05)80360-2. PMid:2231712.

Azad AF, Beard CB. Rickettsial pathogens and their arthropod vectors. Emerg Infect Dis 1998; 4(2): 179-186. http://dx.doi.org/10.3201/ eid0402.980205. PMid:9621188.

Bassini-Silva R, Jacinavicius FC, Mendoza-Roldan JA, Daemon E, Barros-Battesti DM. Description of Blankaartia shatrovi n. sp. (Acari: Trombiculidae) from Brazil. J Med Entomol 2017; 54(1): 82-90. http:// dx.doi.org/10.1093/jme/tjw149. PMid:28082634.

Boshell J, Kerr JA. Veinticinco especies nuevas de trombidiideos en Colombia. Rev Acad Colomb Cienc 1942; 5(17): 110-127.

Brennan JM. A small collection of chiggers (Acarina: Trombiculidae) from the North Central Pacific. J Parasitol 1965; 51(5): 888-892. http:// dx.doi.org/10.2307/3276181. PMid:5857293.

Brennan JM. Three new species of subgenus Parasecia Loomis (genus Fonsecia) from northeastern Brazil and a key to the included species (Acarina: Trombiculidae). J Parasitol 1969; 55(3): 662-666. http://dx.doi. org/10.2307/3277312. PMid:5815348.

Brennan JM. Endoparasitic chiggers. VI. Neoschoengastia esorhina sp. n. (Acarina: Trombiculidae), a second intranasal chigger of birds. J Parasitol 1971; 57(3): 666-667. http://dx.doi.org/10.2307/3277936. PMid:5090976.

Brennan JM, Goff ML. Keys to the genera ot chiggers of the Western Hemisphere (Acarina: Trombiculidae). J Parasitol 1977; 63(3): 554-566. http://dx.doi.org/10.2307/3280021. PMid:68115.

Brennan JM, Jones EK. New genera and species of chiggers from Panama (Acarina: Trombiculidae). J Parasitol 1961; 47(1): 105-124. http://dx.doi. org/10.2307/3274993.

Brennan JM, Yunker CE. The Chiggers of Panama (Acarina: Trombiculidae). In: Wenzel RL, Tipton VJ, editors. Ectoparasites of Panama. Chicago: Field Mus. Nat. Hist; 1966. p. 221-266.

Burns DA. Diseases caused by arthropods and other noxious animals. In: Burns T, Breathnach S, Cox N, Griffiths C, editors. Rook's Textbook of Dermatology. Oxford: Wiley-Blackwell; 2010. p. 1-61. http://dx.doi. org/10.1002/9781444317633.ch38.

Chomczynski P. A reagent for the single-step simultaneous isolation of RNA, DNA and proteins from cell and tissue samples. Biotechniques 1993; 15(3): 532-534. PMid:7692896.

Confalonieri UE, Carvalho LP. Occurrence of Trombicula (Eutrombicula) batatas (L.) in Gallus gallus domesticus L. in the state of Rio de Janeiro (Acarina, Trombiculidae). Rev Bras Biol 1973; 33(1): 7-10. PMid:4805129.

Crossley DA Jr, Atyeo WT. A new species of chigger, Blankaartia pauli (Acarina: Trombiculidae), from the southeastern United States. J Med Entomol 1972; 9(3): 253-254. http://dx.doi.org/10.1093/jmedent/9.3.253. PMid:5057499.

Ewing HE. New acarina. Part I. General considerations and descriptions of new species from Minnesota, Wisconsin, and Michigan. Bull Am Mus Nat Hist 1913; 32: 93-122.

Ewing HE. A new chigger (Trombicula larvae) from Brazil. Proc Entomol Soc Wash 1925; 27(1): 91-92. 
Ewing HE. Key to known adult Trombiculas (adults of chiggers) of the New World with descriptions of two new species (Acarina: Trombidoidea). Entomol News 1926; 37: 111-113.

Floch H, Abonnenc E. Trombidides de la Guyane Française. Le 'pou d' agouti'. Arch Inst Pasteur Guyane Fr 1941; 20: 1-22.

Floch H, Fauran P. Sur deux espèces du genre "Trombicula" (Acariens, Trombiculidés) nouvelles pour la faune de la Guyane Française: "Trombicula alfreddugesi" (Oudemans, 1910) et "Trombicula sinnamaryi” n. sp. Arch Inst Pasteur Guyane Fr 1956; 17: 1-7.

Fonseca F. Notas de Acareologia I. Papel dos acarianos do gênero Trombicula na transmissão das rickettsias pathogenicas e aplicação dessa hypothese à Rickettsia brasiliensis Montero, 1931. Mem Inst Butantan 1932; 3: 127-133.

Goff ML, Loomis RB, Welbourn WC, Wrenn WJ. A glossary of chigger terminology (Acari: Trombiculidae). J Med Entomol 1982; 19(3): 221 238. http://dx.doi.org/10.1093/jmedent/19.3.221. PMid:7120301.

Goff ML, Gettinger D. Two new species of schoengastiine chiggers (Acari: Trombiculidae) from Brazil and rediagnosis of Arisocerus Brennan, 1970. JMed Entomol 1989; 26(6): 554-558. http://dx.doi.org/10.1093/ jmedent/26.6.554. PMid:2585450.

Hase T, Roberts LW, Hildebrandt PK, Cavanaugh DC. Stylostome formation by Leptotrombidium mites (Acari: Trombiculidae). J Parasitol 1978; 64(4): 712-718. http://dx.doi.org/10.2307/3279967. PMid:98623.

Heyne H, Ueckermann EA, Coetzee L. First report of a parasitic mite, Leptotrombidium (Hypotrombidium) subquadratum (Lawrence) (Acari: Trombiculidae: Trombiculinae), from dogs and children in the Bloemfontein area, South Africa. J S Afr Vet Assoc 2001; 72(2): 105-106. http://dx.doi. org/10.4102/jsava.v72i2.629. PMid:11513258.

Hillis DM, Dixon MT. Ribosomal DNA: Molecular evolution and phylogenetic inference. QRev Biol 1991; 66(4): 411-453. http://dx.doi. org/10.1086/417338. PMid:1784710.

Hoffmann A. Los trombiculideos de Mexico (Acarida: Trombiculidae). México: Universidade Nacional Autonoma de Mexico; 1990.

Jacinavicius FC, Bassini-Silva R, Mendoza-Roldan JA, Muñoz-Leal $S$, Hingst-Zaher E, Ochoa R, et al. A contribution to the knowledge of Quadraseta brasiliensis Goff and Gettinger, 1989 (Trombidiformes: Trombiculidae), with description of the deutonymph instar. Acarologia 2018; 58(2): 442-456.

Kampen H, Scholer A, Metzen M, Oehme R, Hartelt K, Kimmig P, et al. Neotrombicula autumnalis (Acari, Trombiculidae) as a vector for Borrelia burgdorferi sensu lato? Exp Appl Acarol 2004; 33(1-2): 93-102. http:// dx.doi.org/10.1023/B:APPA.0000029975.92510.90. PMid:15285141.

Kearse M, Moir R, Wilson A, Stones-Havas S, Cheung M, Sturrock $S$, et al. Geneious basic: an integrated and extendable desktop software platform for the organization and analysis of sequence data. Bioinformatics 2012; 28(12): 1647-1649. http://dx.doi.org/10.1093/bioinformatics/ bts199. PMid:22543367.

Kethley J. Acarina: Prostigmata (Actinedida). In: Dindal DL editors. Soil Biology Guide. New York: John Wiley \& Sons; 1990. p. 667-756.

Labruna MB, Whitworth T, Horta MC, Bouyer DH, McBride JW, Pinter A, et al. Rickettsia species infecting Amblyomma cooperi ticks from an area in the state of São Paulo, Brazil, where Brazilian spotted fever is endemic. J Clin Microbiol 2004; 42(1): 90-98. http://dx.doi.org/10.1128/ JCM.42.1.90-98.2004. PMid:14715737.
Linnaeus C. Systema naturae per regna tria naturae, secundum classes, ordines, genera, species, cum characteribus differentiis, synonymis, locis. Holmiae: Laurentii Salvii; 1758. p. 824

Makol J, Korniluk M. Blankaartia acuscutellaris (Walch, 1922) (Actinotrichida: Trombiculidae) collected from the great snipe Gallinago media (Latham, 1787) (Charadriformes: Scolopacidae) in Poland - new host and country record for chigger mite genus and species. Acarologia 2017; 57(3): 555-562.

Michener CD. Taxonomic and bionomic notes on some panamanian chiggers (Acarina, Trombiculinae). Ann Entomol Soc Am 1946; 39(1): 411-417. http://dx.doi.org/10.1093/aesa/39.3.411.

Mitková K, Berthová L, Kalúz S, Kazimírová M, Burdová L, Kocianová E. First detections of Rickettsia helvetica and $R$. monacensis in ectoparasitic mites (Laelapidae and Trombiculidae) infesting rodents in south-western Slovakia. Parasitol Res 2015; 114(7): 2465-2472. http://dx.doi.org/10.1007/ s00436-015-4443-x. PMid:25843569.

Nadchatram M, Goff ML. A new species of Blankaartia (Megaciella) parasitic on a migratory bird in Irian, New-Guinea (Acari: Trombiculidae). J Med Entomol 1980; 17(3): 218-220. http://dx.doi.org/10.1093/ jmedent/17.3.218.

Navajas M, Gutierrez J, Bonato O, Bolland HR, Mapangou-Divassa S. Intraspecific diversity of the cassava green mite Mononychellus progressivus (Acari: Tetranychidae) using comparisons of mitochondrial and nuclear ribosomal DNA sequences and cross breeding. Exp Appl Acarol 1994; 18(6): 351-360. http://dx.doi.org/10.1007/BF00116316. PMid:7628252.

Ogrzewalska M, Pinter A. Ticks (Acari: Ixodidae) as ectoparasites of Brazilian wild birds and their association with rickettsial diseases. Braz J Vet Res Anim Sci 2016; 53(1): 1-31. http://dx.doi.org/10.11606/ issn.1678-4456.v53i1p1-31.

Ornelas-Almeida MA, Oliveira FR, Silva AE, Moreira EL, Maia PC, Fátima Cardoso Duarte L, et al. Nodular trombiculinosis caused by Apolonia tigipioensis, Torres and Braga (1938), in an ostrich (Struthio camelus) and a house sparrow (Passer domesticus). Vet Parasitol 2007; 150(4): 374-377. http://dx.doi.org/10.1016/j.vetpar.2007.09.020. PMid:17981395.

Otto JC, Wilson KJ. Assessment of the usefulness of ribosomal 18S and mitochondrial COI sequences in Prostigmata phylogeny. In: Proctor HC, Norton RA, Colloff MJ, editors. Acarology: Proceedings of the 10th International Congress. Melbourne: CSIRO Publishing; 2001. p. 100-109.

Oudemans AC. Acarologische aanteekeningen XXXIII. Entomol Ber (Amst) 1910; 3: 83-90.

Poinar G Jr, Poinar R. Parasites and pathogens of mites. Annu Rev Entomol 1998; 43(1): 449-469. http://dx.doi.org/10.1146/annurev. ento.43.1.449. PMid:9444754.

Radford CD. New larval mites of the family Trombiculidae (Acarina: Prostigmata). Parasitology 1957; 47(1-2): 138-144. http://dx.doi. org/10.1017/S0031182000021831. PMid:13441310.

Regnery RL, Spruill CL, Plikaytis BD. Genotypic identification of rickettsiae and estimation of intraspecies sequence divergence for portions of two rickettsial genes. J Bacteriol 1991; 173(5): 1576-1589. http:// dx.doi.org/10.1128/jb.173.5.1576-1589.1991. PMid:1671856.

Ridgely RS, Tudor G. Field guide to the songbirds of South America: the passerines. Austin: University of Texas Press, 2009. 750 pp.

Ripka G, Stekolnikov AA. First finding of the chigger mite Blankaartia acuscutellaris (Acari: Trombiculidae) on a human host in Europe. Belg J Entomol 2006; 8(2): 147-151. 
Roux V, Raoult D. Phylogenetic analysis of members of the genus Rickettsia using the gene encoding the outer-membrane protein $\mathrm{rOmpB}(o m p B)$. Int J Syst Evol Microbiol 2000; 50(Pt 4): 1449-1455. http://dx.doi. org/10.1099/00207713-50-4-1449. PMid:10939649.

Schluger EG. New red mites (Acari, Trombidiidae) of the fauna of the USSR. Entomol Obozr 1948; 30: 157-164. [in Russian]

Shatrov AB, Stekolnikov AA. Redescription of a human-infesting European trombiculid mite Kepkatrombicula desaleri (Acari: Trombiculidae) with data on its mouthparts and stylostome. Int J Acarol 2011; 37(sup1): 176-193. http://dx.doi.org/10.1080/01647954.2010.548342.

Shaw G, Nodder FP. Natural vivarii. Nat's Misc 1790; 2(42)

Simon C, Frati F, Beckenbach A, Crespi B, Liu H, Flook P. Evolution, weighting, and phylogenetic utility of mitochondrial gene sequences and a compilation of conserved polymerase chain reaction primers. Ann Entomol Soc Am 1994; 87(6): 651-701. http://dx.doi.org/10.1093/aesa/87.6.651.

Spalding MG, Wrenn WJ, Schwikert ST, Schmidt JA. Dermatitis in young Florida sandhill cranes (Grus canadensis pratensis) due to infestation by the chigger, Blankaartia sinnamaryi. J Parasitol 1997; 83(4): 768-771. http://dx.doi.org/10.2307/3284263. PMid:9267428.

Stekolnikov AA. Two new species of chigger mites (Acari: Trombiculidae) close to Neotrombicula minuta, application of nonlinear multivariate statistics. Acarina (Mosc) 2008; 16(1): 21-29.

Stekolnikov AA, Daniel M. Chigger mites (Acari: Trombiculidae) of turkey. Zootaxa 2012; 3216: 1-104.

Stekolnikov AA, Santibáńez P, Palomar AM, Oteo JA. Neotrombicula inopinata (Acari: Trombiculidae) - a possible causative agent of trombiculiasis in Europe. Parasit Vectors 2014; 7(1): 90. http://dx.doi.org/10.1186/17563305-7-90. PMid:24589214.

Takahashi M, Misumi H, Urakami H, Nakajima S, Furui S, Yamamoto $S$, et al. Mite vectors (Acari: Trombiculidae) of scrub typhus in a new endemic area in northern Kyoto, Japan. J Med Entomol 2004; 41(1): 107 114. http://dx.doi.org/10.1603/0022-2585-41.1.107. PMid:14989353.

Taufflieb R. Trois nouveaux Trombiculidae (Acarina) du Sénégal. Acarologia 1972; 14(2): 190-197. PMid:4668051.
Taufflieb R, Mouchet J. Revue des Trombiculidae du Cameroun et description de huit espèces et sous-espèces nouvelles. Acarologia 1959; 1(2): 228-245.

Torres S, Braga W. Nova parasitose em pintos (nota prévia). Rev Bras Med Vet 1938; 3: 171-172.

Varma MGR. Mites (Family Trombiculidae) parasitizing birds migrating from Africa to Europe. Bull World Health Organ 1964; 31: 411-416. PMid:14267750.

Vercammen-Grandjean PH. Trombiculidae larvaires de l'Afrique septentrionale et centrale. Huit especes nouvelles et six sous-genres nouvelles (Acarina). Arch Inst Pasteur Alger 1960; 38: 50-69. PMid:13841742.

Walter DE, Krantz GW. Collecting, rearing, and preparing specimens. In: Krantz GW,Walter DE, editor. A manual of acarology. Lubbock: Tech University Press; 2009. p. 83-96.

Walch E. On Trombicula deliensis, problably carrier of the pseudotyphus and on other Trombicula species of Deli. Kitasato Arch Exp Med 1923; 5: 63-83.

Weitzel T, Dittrich S, López J, Phuklia W, Martinez-Valdebenito C, Velásquez K, et al. Endemic scrub typhus in South America. N Engl J Med 2016; 375(10): 954-961. http://dx.doi.org/10.1056/NEJMoa1603657. PMid:27602667.

Wharton GW, Fuller HS. A manual of the chiggers: The biology, classification, distribution and importance to man of the larvae of the family Trombiculidae (Acarina). Washington: Entomological Society of Washington; 1952. p. 185. (Memoirs of the Entomological Society of Washington; vol. 4).

Wohltmann A, du Preez L, Rödel MO, Köhler J, Vences M. Endoparasitic mites of the genus Endotrombicula Ewing, 1931 (Acari: Prostigmata: Parasitengona: Trombiculidae) from African and Madagascan anurans, with description of a new species. Folia Parasitol (Praha) 2007; 54(3): 225-235. http://dx.doi.org/10.14411/fp.2007.031. PMid:19245195.

Wohltmann A, Kohler J, Martin P. Endoparasitic mite infections of anuran amphibians from Bolivian montane rain forests, with descriptions of two new Hannemania species (Acari: Parasitengona: Trombiculidae: Leeuwenhoekiinae). Org Divers Evol 2006; 6(2): 141-150. http://dx.doi. org/10.1016/j.ode.2005.07.003. 
Appendix 1. Type material and allotments examined at the USNM Acari Collection

Blankaartia alleei (Ewing, 1926) - Material: PANAMA - 10 larvae (RML 40415) in Cerro Pirre, Darién, 7-II-1961, Hydrochoerus hydrochaeris; 2 larvae (\#160), in Juan Mima, Canal Zone, 29-II-1944, Crotophaga ani; 1 larva (\#130), in same locality, 3-II-1944, Egretta caerulea (= Florida caerulea caerulea); 1 larva (\#34), near the Chagres River, Canal Zone, 29-X-1945, "drift log"; Charles D. Michener coll.

Blankaartia amersoni (Brennan, 1965) - Material: TRINIDAD - 2 larvae (RML 45755), Soldado Rock, 9-V-1965, Anous stolidus; USA: 1 larva (RML 45767), at the Sand Island, Johnston Atoll, 6-I-1965, Anous stolidus; 1 larva (RML 46205), same locality, 11-VII-1965, Onychoprion fuscatus (= Sterna fuscata); 3 larvae (RML 46207), same locality and host, 12-VII-1963; 2 larvae (RML 46208), same locality and host, 30-VII-1965; 1 larvae (RML 46206), same locality, VIII-1965, Bulweria bulwerii, Thomas H. G. Aitken coll.

Blankaartia arremonops (Brennan \& Jones, 1961) - HOLOTYPE: larva (RML 35280), at the Coco Plantation, Panama, 4-V-1955, Arremonops conirostris, Gordon Field coll.

Blankaartia marui (Brennan \& Yunker, 1966) - HOLOTYPE: larva (RML 40982), in Cerro Azul, Panama, 29-V-1961; Nycticorax nycticorax. PARATYPES: 2 larvae (RML 40983), same data.

Blankaartia sinnamaryi (Floch \& Fauran, 1956) - Material: JAMAICA: 3 larvae (AP23876), St. Thomas, Corn Puss Gap, 14-XI-1946, Myadestes genibarbis; PANAMA - 2 larvae (RML 44025), Gamboa, Canal Zone, 26-X-1961, Baryphthengus ruficapillus; 5 larvae (RML 35309), Coiba Island, 3-I-1956 to 13-II-1956, "Bird"; 1 larva (RML 35330), same locality, 3-I-1956 to 13-II-1956, "Bird"; 1 larva (RML 35313), same locality, 3-I-1956 to 13-II-1956, "Bird"; 4 larvae (RML 40638), Almirante, Bocas del Toro, 23-I-1961, Myiozetetes sp.; 16 larvae (RML 40639), same locality and host, 24-I-1961; 1 larva (RML 40640), same data; 1 larva (RML 40641), same data; 2 larvae (RML 40642), same locality and host, 25-I-1961; 1 larva (RML 40647), same locality and host, 3-II-1961; 2 larvae (RML 40644), same locality, 27-I-1961, Piranga rubra; 22 larvae (RML 40646), same locality, 2-II-1961, Sporophila corvina; 3 larvae (RML 40648), same locality, 14-II-1961, Aramides cajaneus (=Aramides cajanea); 1 larva (RML 40649), same locality, 16-II-1961, Bucconidae; 7 larvae (RML 40636), same locality, 9-I-1961, Taraba major; 2 larvae (RML 40645), same locality, 27-I-1961, Aratinga finschi; 1 larva (RML 43831), same locality, 25-IX-1961, Geothlypis formosa (= Oporornis formosus); 1 larva (RML 43284), same locality, 4-VIII-1961, Xiphorhynchus guttatus; 1 larva (RML 40650), same locality, 3-II-1961, Zentrygon lawrencii (= Geotrygon lawrencii); 1 larva (RML 43767), Rio Changena, Bocas del Toro, 22-IV-1961, Catharus ustulatus (= Hylocichla ustulata); 1 larva (43975), same locality, IX-1961, Trogon massena; 1 larva (RML 43702), same locality, 20-IX-1961, Zentrygon lawrencii (= Geotrygon lawrencii); TRINIDAD: 4 larvae (\#33810), Melajo Forest, Sangre Grande, I-1956, Pitangus sulphuratus; 1 larva (\#33898), same locality and host, 24-IV-1954; 1 larva (\#33831), same locality, 20-XII-1955, Thamnophilus doliatus (= Thamnophilus fraterculus); 1 larva (\#33839), same data; 6 larvae (\#33883), same locality, 28-III-1956, Tachyphonus rufus; 2 larvae (\#34137), same locality, 10-VII-1956, Crotophaga ani; 1 larva (\#33840), same locality, 29-XI-1956, Tyrannus melancholicus; 6 larvae (\#33842), same locality, 4-I-1956, Galbula ruficauda; 1 larva (\#33843), same locality, 6-XII-1956, Myiopagis gaimardii; 5 larvae (\#33802), same locality, 1-III-1956, Amazona amazonica; 3 larvae (\#33839), same locality, 20-XII-1956, Thamnophilus doliatus; 1 larva (\#34047), same locality and host, 3-VII-1956; 1 larva (\#34135), same locality, 10-VII-1956, Myiodynastes maculatus; 1 larva (\#34669), same locality, 24-XII-1959, Xiphorhynchus guttatus; 1 larva (\#37051), Churchill-Roosevelt Highway, 29-XI-1956, Tyrannus savana (= Muscivora tyrannus); 1 larva (\#35073), William Tr. Foster Rd., 1-I-1959, Myiophobus fasciatus; 2 larvae (\#36681), Elgin Trace, Vega de Oropouche, 2-II-1960, Tolmomyias flaviventris; 2 larvae (\#36674), same locality, 29-XII-1959, Myiophobus fasciatus; 2 larvae (\#36684), same locality and host, 2-II-1960; 1 larva (\#36673), same locality, 29-XII-1959, Tolmomyias flaviventris; 2 larvae (\#36681), same locality and host, 2-II-1960; 1 larva (\#38214), Vega de Oropouche, 10-I-1961, Campephilus melanoleucos (= Phloeceastes melanoleucos); 1 larva (\#35052), same locality, 7-X-1959, Cyclarhis gujanensis; 2 larvae (\#36771), same locality, 15-XII-1959, Pipra erythrocephala; 3 larvae (\#36688), same locality and host, 8-XII-1959; 1 larva (\#36690), Fort Reid, 16-II-1960, Myiophobus fasciatus; 1 larva (\#33660), same locality, 26-V-1955, Tyrannus melancholicus; 1 larva (\#35092), 3-V-1959, Columbina talpacoti (= Columbigallina talpacoti); 1 larva (\#36690), same locality, 2-III-1960, Thamnophilus doliatus; 3 larvae (\#34682), Granville, 12-III-1956, Ciccaba virgata; USA: 2 larvae (\#45011), Cameron Co., Texas, 7-V-1962, Dumetella carolinensis; 1 larva (\#38715), same locality, 23-IV-1963, Hylocichla mustelina, Richard B. Eards coll.

Blankaartia wetmorei (Brennan \& Yunker, 1966) - HOLOTYPE: larva (RML 43234), at Fort Kobbe, Canal Zone, Panama, 20-VII-1961, Nyctanassa violacea. PARATYPES: 2 larvae (RML 43234), same data, Frank Todd coll. 